\title{
Aspilia Africana extracts as organic corrosion inhibitor of mild steel in corrosive acidic media.
}

\author{
J. C. Osuwa ${ }^{1}$ and C. Okere ${ }^{2}$ \\ Department of Physics, Michael Okpara University of Agriculture, Umudike PMB 7267, Abia State, Nigeria
}

\begin{abstract}
Extracts of Aspilia Africana as organic corrosion inhibitor of mild steel in corrosive media of sulphuric acid $\left(\mathrm{H}_{2} \mathrm{SO}_{4}\right)$ and hydrochloric acid $(\mathrm{HCl})$ has been investigated at room temperature of $25.6^{\circ} \mathrm{C}$ using gravimetric (weight loss) technique. Mild steel coupons of $30 \mathrm{~mm}^{2}$ and $0.45 \mathrm{~mm}$ thickness were exposed for varying durations in steps of 24 hours, in $0.5 \mathrm{M}$ of $\mathrm{H}_{2} \mathrm{SO}_{4}$ and $0.5 \mathrm{M} \mathrm{HCl}$ mixed with varying concentrations of Aspilia Africana extract $(100 \mathrm{mg} / \mathrm{L}-700 \mathrm{mg} / \mathrm{L})$. The results show that corrosion rates dropped from maximum value of $8.3 \times 10^{-3}$ mpy (mills per year) for the uninhibited medium to maximum value of $1.5 \times 10^{-3}$ mpy for the inhibited medium of $0.5 \mathrm{M} \mathrm{H}_{2} \mathrm{SO}_{4}$ with extract concentration of $100 \mathrm{mg} / \mathrm{L}$. Corresponding values for $0.5 \mathrm{M} \mathrm{HCl}$ are $10.0 \times 10^{-3}$ to $2.5 \times 10^{-3}$ mpy. Further increases in the extract concentrations result in less drastic decrease in the corrosion rate as reported in this paper. Values of corrosion inhibition efficiencies of 58.5-98.8\% for $\mathrm{H}_{2} \mathrm{SO}_{4}$ and 70-90.9\% for $\mathrm{HCl}$ media occurred for various extract concentrations with the highest values occurring at $600 \mathrm{mg} / \mathrm{L}$. Thus, Aspilia Africana extracts whose plants are bountiful in the tropical forests of West, East and Central Africa, provide good corrosion inhibition for mild steel.
\end{abstract}

Keywords: Aspilia Africana extract, corrosion inhibition, gravimetric technique, inhibition efficiencies.

\section{Introduction}

Corrosion of metals involves anodic and or cathodic reactions [1] with reverse economic, environmental and safety consequences. The use of inhibitors is one of the most practical ways of protecting metals from corrosion, especially in acidic media [2]. The wide use of acid solutions in industries for acid pickling of steel, chemical cleaning and processing, ore production and oil well acidizing among others, are corrosion prone processes. Synthesized commercial corrosion inhibitors in use, such as chromates, silicates and organic amines, are expensive, toxic and non environmental friendly. This has led to continued search for low cost and effective inhibitors with low or zero environmental impact.

Plant extracts which are low-cost and biodegradable have therefore been the focus of intense research on corrosion inhibitors for some decades due to their economic and environmental benefits. As early as 1930, plant extracts (dried stems, leaves and seeds) of Chelidonium majus were used as corrosion inhibitors for steel in $\mathrm{H}_{2} \mathrm{SO}_{4}$ pickling baths [1]. By 1972 studies of the extract of Hibiscus subdariffa (Karkode) as the corrosion inhibitor for $\mathrm{Al}$ and $\mathrm{Zn}$ in $\mathrm{HCl}$ and $\mathrm{NaOH}$ solutions had been carried out. In 1980s [3,4] reported the inhibition effect of some plant leaves (Opunta, Aleo eru) and fruit peels (orange, mango) on the corrosion of steel, aluminum, zinc and copper in acids and aluminum in $\mathrm{NaOH}$ solution. Also, [5,6] reported Azadirachta and Vernonia amygdalina (bitter leaf) leaves extracts as good corrosion inhibitors for steel in $\mathrm{HCl}$ and $\mathrm{H}_{2} \mathrm{SO}_{4}$ solutions.

By $21^{\text {st }}$ century, a large volume of literature was available about plant leaves extracts as effective corrosion inhibitors of iron or steel in acidic media. Some of the studied plants include henna [7-10] Nype fruticans Wurumb [11,12] Azadirachta Indica [13] Acalypha Indica [14] Zenthoxylum alatum [15,16] among others. Through these studies, it was established that the inhibition performance of plant extracts is normally ascribed to the presence in their composition of complex organic species such as tannins, alkaloids and nitrogen bases, amino acids and proteins as well as hydrolysis products. These organic compounds contain polar functions with $\mathrm{N}, \mathrm{S}, \mathrm{O}$ atoms as well as conjugated double bonds or atomic rings in their molecular structures which are the major adsorption centers. However, given the vast varieties of plants, the data regarding the use of plant leave extracts as corrosion inhibitors are still limited. In this work, Aspilia Africana (African Merrygold) leaf extract has been investigated as corrosion inhibitor with a focus on the corrosion characteristics of lowcarbon mild steel in $\mathrm{HCL}$ and $\mathrm{H}_{2} \mathrm{SO}_{4}$ media with and without the inhibitor.

\subsection{Materials}

\section{Experimental Details}

The materials used in this study of corrosion inhibition of mild steel include sulphuric acid $\left(\mathrm{H}_{2} \mathrm{SO}_{4}\right)$, hydrochloric acid $(\mathrm{HCl})$, ethanol, concentrated Nitric acid, distilled water, beakers, measuring cylinder, electronic weighing balance, venier caliper, micrometer screw gauge, wooden stick, reflux apparatus, heating mantle, water bath, grinding stone, abrasive papers, thread, masking tape and emery papers 
Aspilia Africana extracts as corrosion inhibitor of varying concentrations ranging from $100 \mathrm{mg} / \mathrm{L}$ to $700 \mathrm{mg} / \mathrm{L}$ were also used, while the corrosive media consist of $0.5 \mathrm{M} \mathrm{H}_{2} \mathrm{SO}_{4}$ and $0.5 \mathrm{M} \mathrm{Hcl}$. Sheet of mild steel was obtained from Universal Steel Company Limited, Lagos, Nigeria.

\subsection{Preparation of mild steel coupons}

The sheet of mild steel was cut into coupons of $30 \mathrm{~mm} \times 30 \mathrm{~mm}$ with thickness of $0.45 \mathrm{~mm}$. A hole of uniform diameter of $3 \mathrm{~mm}$ was drilled in each coupon to facilitate its suspension in the test solution.

The coupons were mechanically cleaned followed by polishing with emery paper to expose shining polished surface. To remove any oil and organic impurities the coupons were degreased with ethanol and finally washed with distilled water, dried in air and then stored in a desicator. Accurate weight of each coupon was taken using electronic balance and recorded as initial weight $\mathrm{W}_{\mathrm{i}}$. The coupons were labeled in a manner to avoid any mix up.

\subsection{Determination of corrosion rate}

Weight ioss technique was employed in the experiment as follows. Each coupon was weighed using digital weighing balance and recorded as weight $\mathrm{W}_{\mathrm{i}}$. Then $200 \mathrm{ml}$ of a corrosive medium was introduced into reaction beakers. The pre-weighed coupons were fully immersed into each of the test media using twine tied to a small stick for support. The experimental set-up was kept in a cool place in the laboratory away from direct sunlight, while the time of exposure for each coupon was carefully noted. Each coupon was retrieved from the test medium in intervals of 24 hours and visual observation was carried out on each coupon retrieved from the solution.

The corroded coupons were washed under running water dipped in ethanol and acetone and then airdried. The coupons were reweighed and the final weights, $\mathrm{W}_{\mathrm{f}}$ recorded. Weight losses, $\Delta \mathrm{W}=\mathrm{W}_{\mathrm{i}}-\mathrm{W}_{\mathrm{f}}$ were calculated. The above process was carried out for Aspilia Africana concentrations of $100 \mathrm{mg} / \mathrm{L}, 200 \mathrm{mg} / \mathrm{L}$, $300 \mathrm{mg} / \mathrm{L}, 400 \mathrm{mg} / \mathrm{L}, 500 \mathrm{mg} / \mathrm{L}, 600 \mathrm{mg} / \mathrm{L}$ and $700 \mathrm{mg} / \mathrm{L}$ in the two media of $0.5 \mathrm{M} \mathrm{H}_{2} \mathrm{SO}_{4}$ and $0.5 \mathrm{M} \mathrm{HCl}$. The corrosion rate may be expressed as an increase in corrosion depth per unit time and the corrosion rate equation 1 , in mpy is given by :

$$
\mathbf{C} \mathbf{R}=\mathbf{K} \Delta \mathbf{W} / \mathbf{\rho A t}
$$

where $\mathrm{K}=$ constant for unit conversion

$\Delta \mathrm{W}=$ weight loss of coupon

$\mathrm{P}=$ density of coupon

$\mathrm{A}=$ area of coupon
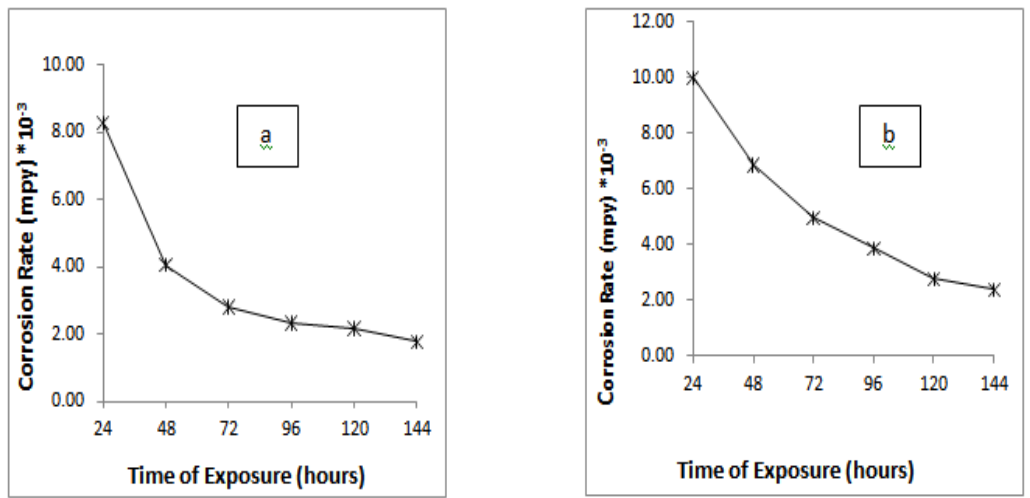

Fig. 1: Corrosion rate values of mild steel in (a) $0.5 \mathrm{M} \mathrm{H}_{2} \mathrm{SO}_{4}$ and (b) $0.5 \mathrm{M} \mathrm{HCl}$ for uninhibited corroded coupons

\section{Results and Discussions}

Figure 1(a) shows that the corrosion rate of mild steel in uninhibited $0.5 \mathrm{M} \mathrm{H}_{2} \mathrm{SO}_{4}$ decreased significantly till the 72 nd hour of exposure and the decrease then tends to be exponential up to 144 hours of exposure and beyond. Figure 1 (b) also shows great decline in the $0.5 \mathrm{M} \mathrm{HCl}$ corrosion rate for uninhibited coupon of mild steel all through the entire hours of exposure. The rate of deterioration was consistent with the hour of exposure. For both acid media, the corrosion rate reduced significantly as the hour of exposure increased and this could be that the metal developed passivity in addition to the effects of layers of corroded metal.

Figures 2 (a) and (b) show the corrosion rates in $0.5 \mathrm{M} \mathrm{H}_{2} \mathrm{SO}_{4}$ and $0.5 \mathrm{M} \mathrm{HCl}$ for various concentrations of Aspilia Africana. With extract concentration of only $100 \mathrm{mg} / \mathrm{L}$ the corrosion rate in $0.5 \mathrm{M} \mathrm{H}_{2} \mathrm{SO}_{4}$ decreased to $1.5 \times 10^{-3} \mathrm{mpy}$ in the first 24 hours from $8.3 \times 10^{-3} \mathrm{mpy}$ for the uninhibited case. Also, minimum value of about $0.2 \times 10^{-3}$ mpy occurred for extract concentration of $600 \mathrm{mg} / \mathrm{L}$ in the first 24 hours. The corresponding values for $0.5 \mathrm{M} \mathrm{HCl}$ as shown in fig. 2 (b) are $2.5 \times 10^{-3}$ mpy for the first 24 hours of $100 \mathrm{mg} / \mathrm{L}$ of extract concentration and a minimum value of about $0.8 \times 10^{-3}$ mpy occurring for concentration of $600 \mathrm{mg} / \mathrm{L}$ after 72 hours. 

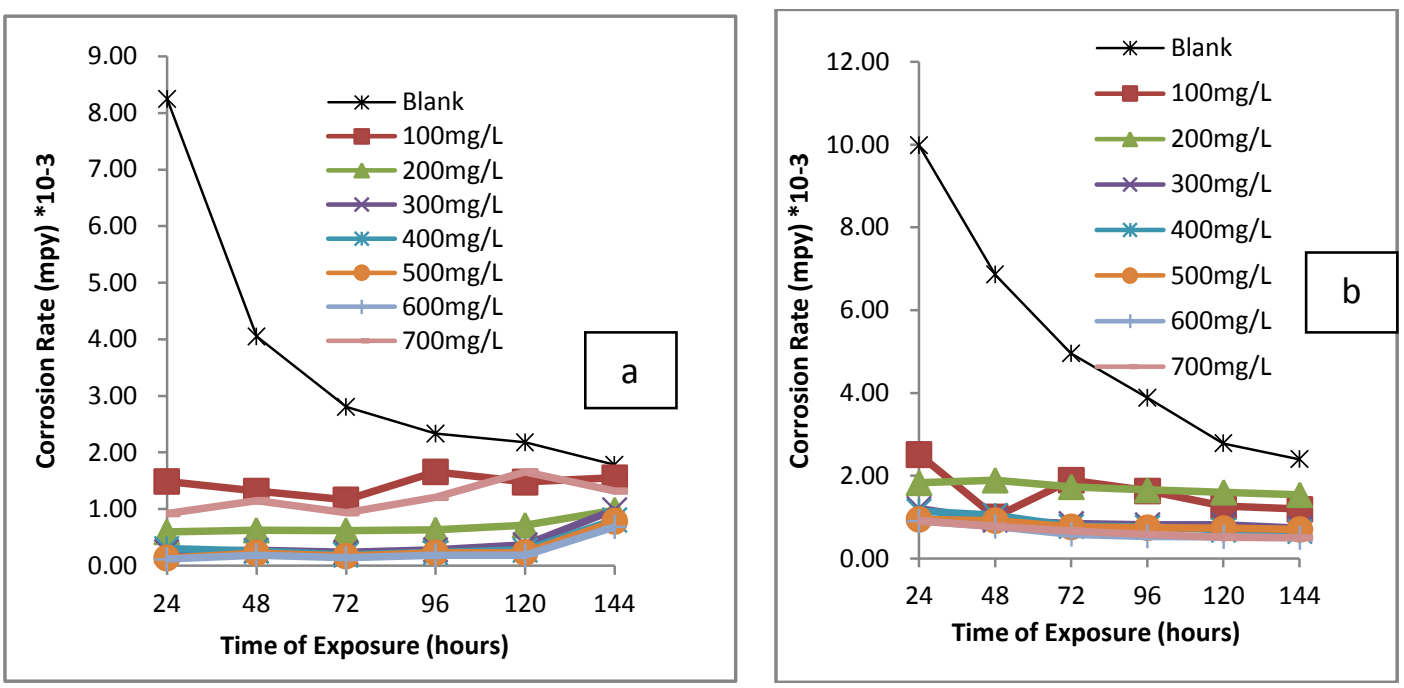

Fig 2: Variation with time of the corrosion rate of mild steel in (a) $0.5 \mathrm{M} \mathrm{H}_{2} \mathrm{SO}_{4}$ (b) $0.5 \mathrm{M} \mathrm{HCl}$ for various concentrations of Aspilia africana extract

Figures 3: (a),(b), (c) and (d) and fig. 4: (a), (b) and (c) show the inhibition efficiencies for various concentrations of Aspilia Africana extract in the two acid media at different exposure time for mild steel. Here, the efficiencies are given by the percentage ratio of the inhibited over the uninhibited corrosion rates for each extract concentration in the two acid media. [5] reported that a mixture of nitrogen and sulphur containing compounds are better inhibitors than either type alone. The extracts of Aspilia Africana investigated contain both nitrogen and sulphur atoms, hence, exhibit good performance on the corrosion of mild steel in both $\mathrm{H}_{2} \mathrm{SO}_{4}$ and $\mathrm{HCl}$ media.

The highest inhibition efficiencies of $98.8 \%$ for $\mathrm{H}_{2} \mathrm{SO}_{4}$ was obtained at extract concentration of 600 $\mathrm{mg} / \mathrm{L}$ after 24 hours of exposure while that of $\mathrm{HCl}$ was $90.9 \%$ at the same concentration of $600 \mathrm{mg} / \mathrm{L}$ after 24 hours of exposure.
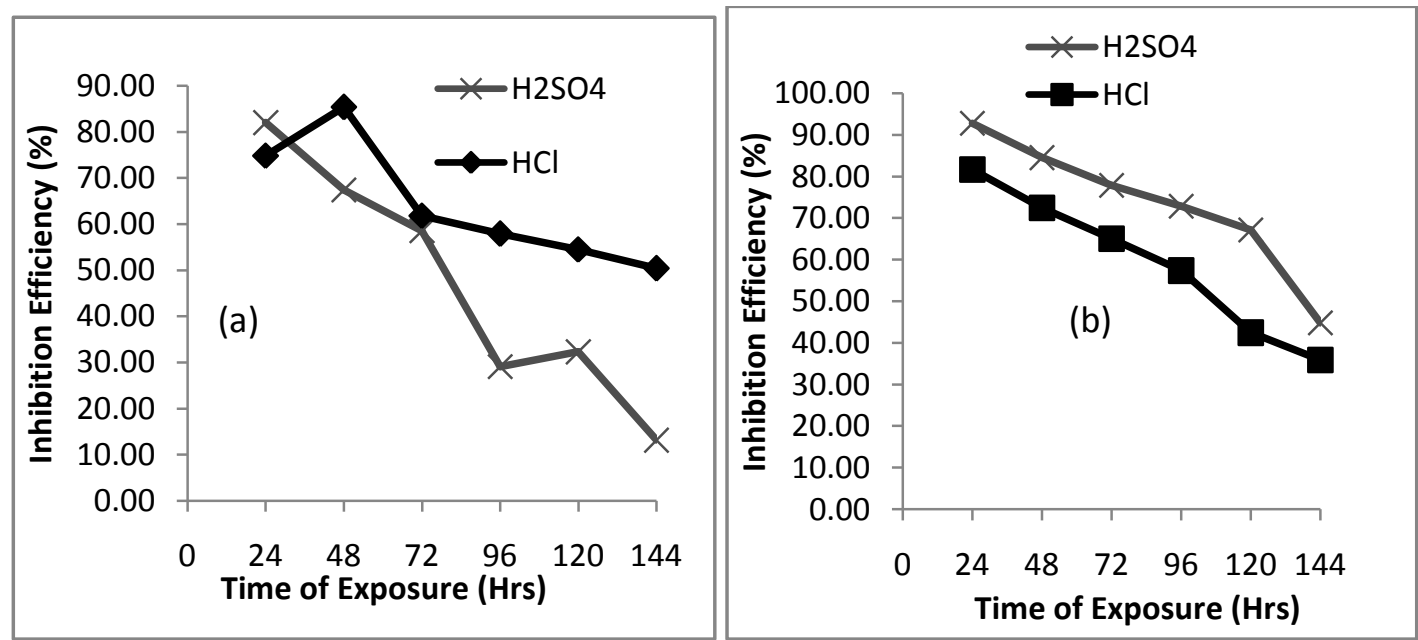
Aspilia Africana extracts as organic corrosion inhibitor of mild steel in corrosive acidic media.
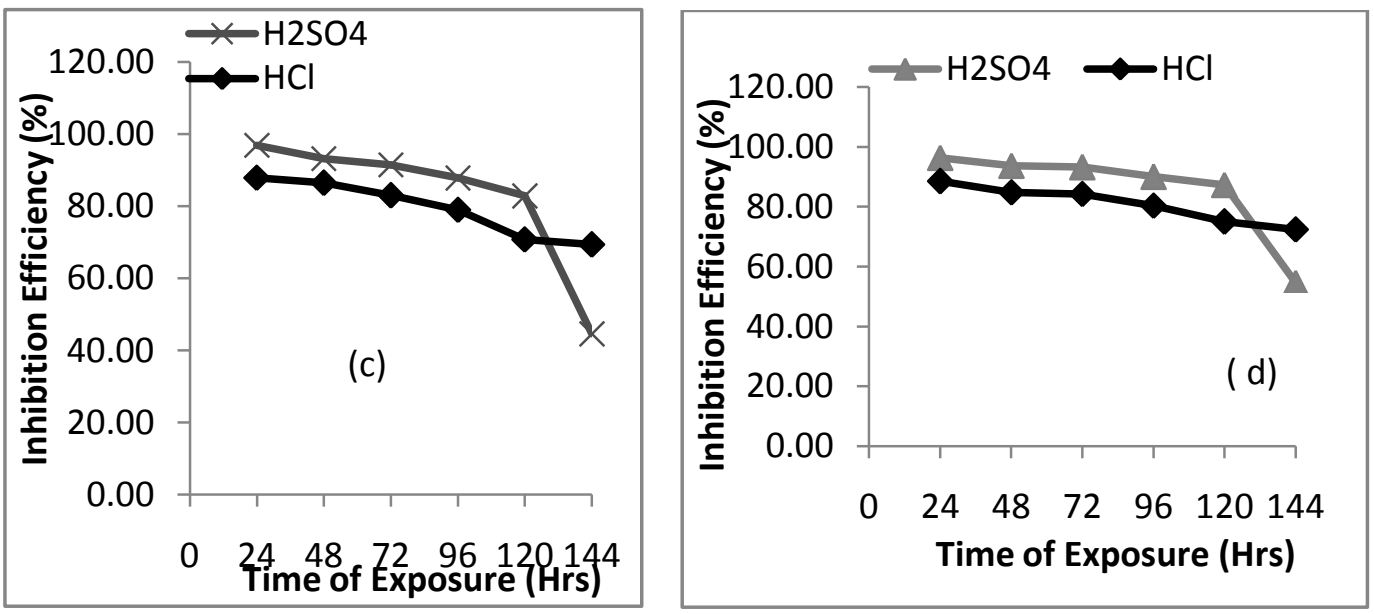

Fig. 3: Variation with time of inhibition efficiency in $0.5 \mathrm{M} \mathrm{H}_{2} \mathrm{SO}_{4}$ and $0.5 \mathrm{M} \mathrm{HCl}$ media for Aspilia Afircana extract of different concentrations (a) $100 \mathrm{mg} / \mathrm{L} \mathrm{(b)} 200 \mathrm{mg} / \mathrm{L} \mathrm{(c)} 300 \mathrm{mg} / \mathrm{L}$ and (d) $400 \mathrm{mg} / \mathrm{L}$.
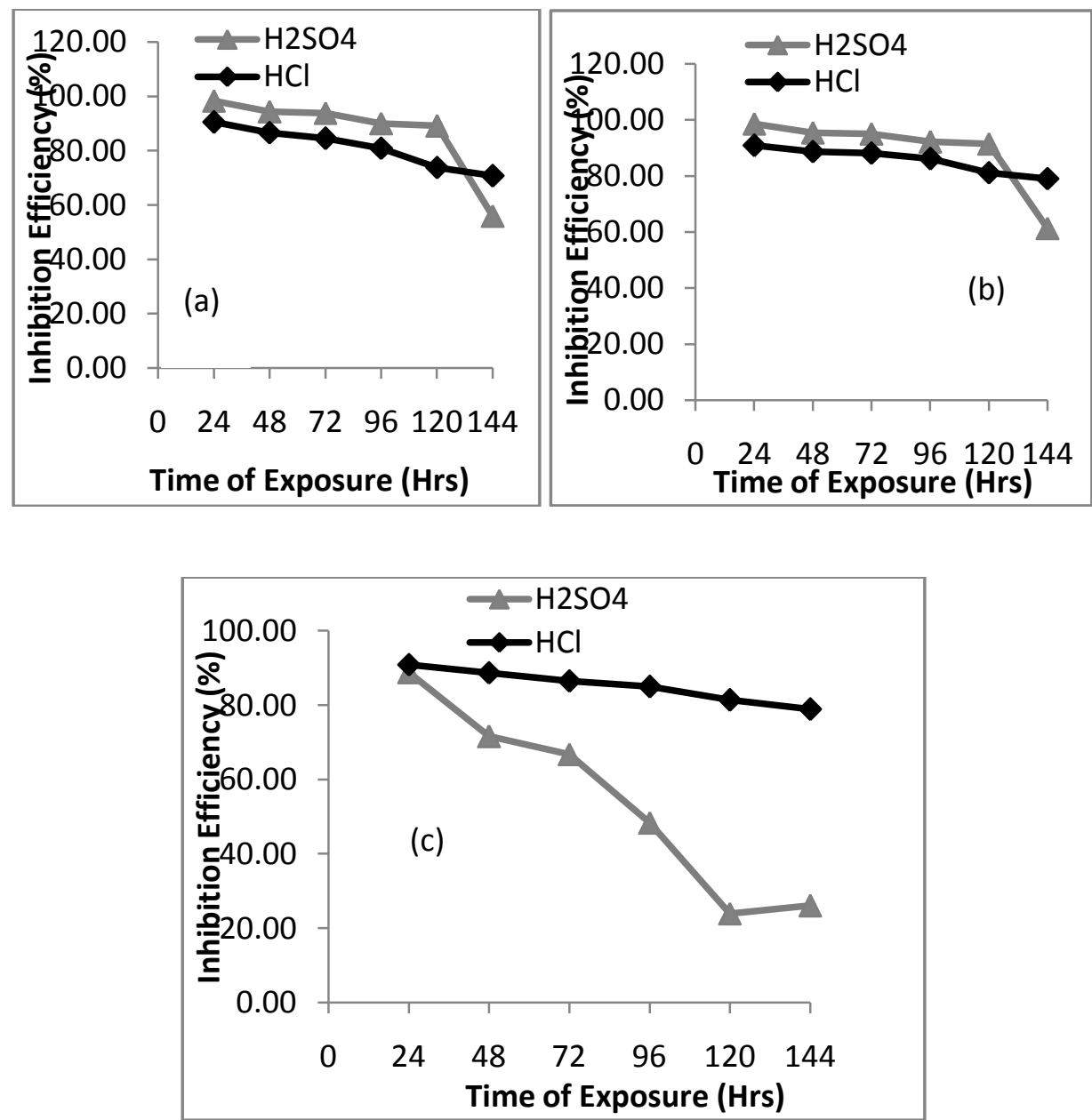

Fig. 4: Variation with time of inhibition efficiency in $0.5 \mathrm{M} \mathrm{H}_{2} \mathrm{SO}_{4}$ and $0.5 \mathrm{M} \mathrm{HCl}$ media for Aspilia Afircana extract of different concentrations (a) $500 \mathrm{mg} / \mathrm{L}$ (b) $600 \mathrm{mg} / \mathrm{L}$ (c) $700 \mathrm{mg} / \mathrm{L}$ and .

\section{CONCLUSION}

The inhibitive effect of Aspilia Africana extract on the corrosion rate of mild steel at room temperature has been determined through gravimetric technique. It was found that extract of Aspilia Afircana with as low concentration as $100 \mathrm{mg} / \mathrm{L}$ produced remarkable decrease in the corrosion rate of mild steel in both $0.5 \mathrm{M} \mathrm{H}_{2} \mathrm{SO}_{4}$ and $0.5 \mathrm{M} \mathrm{Hcl}$. Higher concentrations of Aspilia Africana yielded further inhibition of corrosion of mild steel in 
acidic media. Corrosion efficiencies of 58.5-98.8\% for $\mathrm{H}_{2} \mathrm{SO}_{4}$ and $70-90.9 \%$ for $\mathrm{HCl}$ were obtained. The results show that the greater the number of bonds in the extracts the higher the efficiency in the acidic media which occurs by means of hindering both cathodic and anodic processes.

\section{References}

[1] Raja, P. B., Sethuraman, M. G., Strychnos nux- vomica an ecofriendly corrosion inhibitor for milld steel in 1M sulfuric acid medium. Mater. Corros. 60, 2009, 22-28

[2] Trabanelli, G, Inhibirors an old remedy for a new Challenge. Corrosion. 47, 41. 1991, 0-419.

[3] Saleh, R. M., Ismail, A. A., El Hosary, A. A., Corrosion inhibition by naturally occurring substances. VII. The effect of aqueous extracts of some leaves and fruit peels on the corrosion of steel aluminum, zinc and copper in acids. Br. Corros.J. 17, 1982, 131-135

[4] Saleh, R. M., Ismail, A. A., El Hosry, A. A., Corrosion inhibition by naturally occurring substances. IX. The effect of aqueous extracts of some leaves and fruit peels on the corrosion of aluminum in Sodium hydroxide.. Corros. Sci. 23, 1983, 1239-1241

[5] Ekpe, U. I., Ebenso, E. E., Ibok, U. J., Inhibitory actions of Azadirachta Indica leaf extract on the corrosion of mild steel in H2SO4 J. W. Afr. Sci. Assoc. 39, 1994, !3 -30

[6] Loto, C. A., The effect of Vernonia amygdalina (bitter leaf) solution extract on corrosion inhibition of mild steel. Nig. Cor. J. 19, 1997, 20-28

[7] Al- Sehaibani, H., Evaluation of extracts of henna leaves as environmentally friendly corrosion inhibitors for metals. Mater. Wissen Werkst. Tech. 31, 2000, 1060-1063

[8] Chetouani, A., Hammouti, B., Corrosion inhibition of iron in hydrochloric acid solution by naturally henna. Bull. Electrchem. 19, 2000, 23-25

[9] Ostovari, A., Hoseinieh, S., Peikari, M. Shadizadeh, S., Hashemi, S., Corrosion inhibition of mild steel in 1M Hcl solution by henna extract: a comparative study of the inhibition by henna and its constituents (lawsone, Gallic acid, a-DGlucose and tannic acid). Corrosion Science. 51, 2009, 1935-1949

[10] El-Etre, A., Abdallah, M., El-Tantaway, Z. E., Corrosion inhibition of some metals using lawsonia extract. Corros. Sci. 47, 2005, 385-395

[11] Orubite, K. O., Oforka, N. C., Inhibition of the corrosion of mild steel in hydrochloric acid solutions by extracts of leaves of Nypa fruticans' Wurmb. Mater. Lett. 58, 2004, 1768-1772

[12] Orubit-Okorosaye, K., Jack, I.R., Ochei, M., Akaranta, O., Synergetic effect of potassium oxide on corrosion inhibition of mild steel in $\mathrm{HCl}$ medium by extracts of Nypa fruticans' Wurmb. J. Appl.Sci. Environ. Manage. 11, 2007, 27-31

[13] Sharma, S. K., Mudhoo, A., Tain, G., Sharma, T., Corrosion inhibition and adsorption properties of Azadirachta indica mature leaves extract as green inhibitors for mild steel in HNO3. Green Chem. Lett. Rev. 3, 2010, 7-15

[14] Sivaraju, M., Kannan, K., Inhibitive properties of plant extract (Acalypha indica L.) on mild steel corrosion in 1 N phosphoric acid. Inter.J. Chem. Tech. Research. 2, 2010, 1243-1253

[15] Gunasekaran, G., Chauhan. L. R., Eco friendly inhibitor for corrosion inhibition of mild steel in phosphoric acid medium. Electrochim. Acta. 49, 2004, 4387-4395

[16] Chuahan, L. R., Gunasekaran, G., Corrosion inhibition of mild steel by plant extract in dilute $\mathrm{HCl}$ medium. Corros. Sci. 49, 2007, $1143-1161$ 